\title{
A Tentative Study on Teaching Arts in Vocational English Class
}

\author{
Juan Wang \\ Southwest Guizhou Vocational Technical Institute of National Minorities \\ Xingyi 562400, China \\ E-mail: wangjuan6688119@sina.com
}

\begin{abstract}
Nowadays, it is a vigorously-developing project to improve teaching arts in English class. As a result, this article focuses on how to improve English teaching efficiency, how to improve English teaching quality, how to encourage students to participate in studying activities actively as well as how to deal with teaching links at class.
\end{abstract}

Keywords: English class, Improve, Teaching arts, Teaching Link

English teaching is a branch of art as well as science. Therefore, it is increasingly important to think over how to improve English teaching quality, how to encourage students to participate in study actively and how to deal with teaching links at class. Roughly, some necessary teaching arts are as follows:

\section{Introduction Design Arts}

I tell my students that a good beginning is half done at the very beginning of every term. Introduction design can be closely related to the creation of a harmonious and happy atmosphere and attracting students' attention. For example, when I dealt with a text named Happiness is a Choice last term, I employed different ways in two classes. For Pharmacy 3-3 in Grade 2007, I asked students about their choice of happiness among money, happy feelings and health at the very beginning and got different answers. Instead of telling them the definition of "happiness", I gave them a proverb about it--- "If you want to be happy for a few hours, go to get drunk. If you want the happiness to last three years, get married. If you want a life-time happiness, take up gardening. The reason for the last option is this. Gardening is not only useful, it helps you to identify yourself with nature, and thus brings you new joy each day besides improving your health." While in another class, I directly gave students some questions to think over such as "what's happiness?" "Are you happy?" "Are you seeking happiness today?" "Do you remember a time when you were happy?" Once they couldn't give their answers, I said, "you will find it in the title of the text because happiness is a choice in heart and can be defined accordingly. If you want to know more about it, let's move on to the text." In this way, students can be trained in listening and speaking as well as encouraged to learn the text with great interest.

\section{Situational Debate Arts}

Due to the shortage of language environment among Chinese learners of English, we are supposed to select proper teaching means according to the content of textbooks and create English teaching environment in order to stimulate students' enthusiasm and improve their understanding, grasp and use of this language. When teaching "job", students can play the roles of different jobs, such as a doctor with a stethoscope or a farmer with a sickle. As a result, every student can be fully encouraged to participate in class activities. For example, when learning the text called Men's Four -legged Friends? Why or Why Not?, I divided students into two groups to debate against each other.

Pros: dogs are our friends. $\quad$--- keep us company

---do many jobs for us

---be used in sports and police work

Cons: dogs aren’t our friends. -----carry diseases

----cost money and time

---- Bring people to death with their bites

That class witnessed heated debate atmosphere and students enjoyed it very much. As for English vocabulary and phrases, situations can be created to help students to learn and use them because it is easier for students to understand their meanings, enjoy the great interest in learning them and memorize them deeply. For example, I say "Good evening!" to my students every time I enter the classroom and "Good night!" when I leave. Gradually, students are able to distinguish the two phrases. Another example, when dealing with some words expressing food and drinks at class, teachers might as well turn the platform into a food store. Playing the role of a store-keeper, the teacher can ask students "What would you like for breakfast?" and students will answer them. Next, students can take turns to go on with this role-play activity. 


\section{Language Arts}

Vivid class teaching language is an enjoyment for students while dry and boring one is an agony. In order to improve students' interest in English learning, teachers are expected to make the textbook more interesting, make the class more vivid and employ various methods to stimulate students' interest and to help students experience success. For example, the following dialogue will help students to experience the sense of humor embodied in English culture.

Teacher: I lay one egg here, and I lay one egg there. How many eggs are there all together?

Students: No, you can't lay eggs.

Some daily expressions such as "please", "Thank you!" and "I'm sorry." will educate students about politeness and friendly interpersonal relationship. When asking students to answer questions or do something, teachers are expected to say "Would you like...?" or "Will you please...?" to display the tactful beauty of English. When remarking on students' answers or performance, teachers should often use some positive expressions such as "Good", "Good job!", "Wonderful!" and "Marvelous!" to give students confidence, encouragement and a sense of achievement.

The language arts of English lie in how to explore the characteristics and connotations of English beauty and put it into practice to create a beautiful language environment for students and hence to stimulate their interest in experiencing, learning, using and improving the language. As is required by the beauty of teaching language, teachers should speak as much as English instead of Chinese; they should have correct pronunciation and intonation as well as fluent expression; teachers are also expected to create a vivid and humorous class atmosphere instead of a boring and tedious one. Accordingly, teachers should employ various kinds of teaching methods in a direct way. In addition, because interest is the best teacher, teachers are supposed to create a beautiful language environment to attract students to be absorbed in the English class. Only in this way can students' interest be stimulated and therefore their efficiency of study be improved.

\section{Demonstration and Performance Arts}

As is known, it is impossible to fully exert the communicational function of language in life only by creating some real situations at class. In addition to that, students need to understand language by listening to it consciously, which calls for a systematic employment of different teaching means in class. It is true that real situations will help students to experience language in a real way. However, with these situations employed in a comprehensive way, students will have the opportunity to experience language and further use it in life. Besides, demonstration and performance are indispensable skills and means in modern English teaching. It is important for teachers to skillfully employ concrete objects, acts, dialogues and plays to create certain situations. Put into real life situations, students will be unconsciously attracted and absorbed in their roles, hence achieving more knowledge and having their enthusiasm for thinking and practice stimulated. During performance, properties should be used as much as possible, such as in seeing the doctor, shopping, making telephone calls, asking the way and so on, to make students slide into the created situations more easily. If there is no property, students' imagination and aesthetics can be more easily improved. For example, when I taught the present perfect tense, I dropped an old glass on the ground all of a sudden and of course it was broken. Then I asked them a question.

T: What have I just done?

S: You have just broken the glass.

These performances are characterized by simple motions, visualization and operability. Therefore, it is easier for students to be interested in, to accept them and to have greater achievements with less effort. As a result, students will be able to learn about certain situations to use language and its meaning. What's more, students will develop right language habits and improve their own skills in using language flexibly.

To sum up, in order to have high-efficient English class, the former stereotyped teaching pattern must give way to an atmosphere in which teachers and students appreciate the beauty of English together. A teaching environment with the harmonious development of teaching and learning, knowledge and ability, will and emotion should be formed to produce powerful teaching stress. In order to achieve the best teaching effects, artistic teaching is expected to be conducted in class.

\section{Communication and Interaction Arts}

In English class, teachers can create some "information gaps" based on specific activities and students' reality to encourage students to communicate with others with what they have learnt in class. For example, I employed "information gaps"to teach the expressions to ask the way and give directions when I dealt with the text named How Can I Get to the Post Office?. I designed some questions: 1. Do you often ask for directions? 2. From whom do you often ask for directions? 3. Do you always get the right answers? 4. Why are foreign travelers often confused in a Japanese city? 5. What will a Greek do when you ask him /her for directions? 6. Are you sure of getting the right answers when you ask for directions in your hometown? Students would finish reading one paragraph when they answered one question. At the same time, they understood the fact that they would get different answers in different countries when they asked the same question of "How can I get the post office?" was caused by different folk custom. 
In another activity, Student A1 and A2 got a map with some places unmarked, such as the Great Wall Hotel or a bank, which they could get from Student B1 and B2. Meanwhile, B1 and B2 were eager to find some places such as a hospital or McDonald's on their map under the help of A1 and A2.

Due to the information gap between the two groups, they interacted with each other, during which they practiced some necessary sentence patterns such as "Could you tell me where...is?", "Would you please tell me how I can get to ...?" and "Do you mind telling me the way to...?" as well as some positional prepositions and some expressions to give directions.

\section{The Arts of "Turning War to Peace"}

Although class accidents are common, an impolitic approach will lead to a failing class and spoiled teachers' image. On the contrary, a proper approach will achieve a wonderful effect. For example, I came across an expression of "hit itself" when I taught reflexive pronouns. I didn't figure out a proper situation to use it before class. I was about to explain that phrase to students when a butterfly flew around the classroom and then rushed to a window. Suddenly I had an idea and said to students, "It hit itself". Of course, students burst into laughter, "Yes, it hit itself". Here is another example, when I explained "a good sleep", I found a student sleeping in class. So I said, "Please be quiet, she has a good sleep!". As a result, all students burst into laughter and that student inclined her head with embarrassment.

\section{Blackboard Writing Arts}

Writing on blackboard has an indispensable role in class teaching. According to English handwriting arts, the writing of letters should be standardized; the distance among letters, words, sentences and lines should not be too long or short; the layout should be neat and clean. Besides, there should be a reasonably-designed outline in which a board is employed for each class and certain small parts can be used for repeated writing and erasing; the title should be put to the top middle part; the key and difficult points should be written in the middle part while the minor points on sides for later use. The middle part is expected to have clear outline, emphasized key points as well as concise content.

\section{Various Teaching Forms}

A variety of teaching forms can be employed to integrate knowledge with interest. Students tend to feel tired and their attention will be distracted when the class is coming to the end. Therefore, some discussions can be conducted to attract students' attention. I once divided my students into four groups to have a discussion when we learnt Gambling.

Gambling ----

\section{A social evil;}

Injurious not noly to the individuals but also to the society;

Discourages habits of industry;

Throws a man and his family into misery

Ends up in theft, robbery or in crime of violence

In the end, I summed it up--- "We will never develop the habits of gambling. We must tell people to stay away from gambling......."

According to psychology, constantly changing stimulations will attract and keep people's attention. A certain teaching form will attract students' attention at the very beginning but fail to keep it after a relatively long period. Therefore, it is particularly important to change teaching forms from time to time. For example, a text can be read by teachers, individual students, small groups and the whole class. Dialogues can be conducted among students, a teacher and a student, groups, male and female students and so on. Different forms to deal with a dialogue such as reading aloud, reciting, interviews and performances can be employed. A text can be recited, retold, summarized, changed into dialogues or role-play activities in order to help students to memorize what they have learnt. Besides, different means can be used, such as tapes, projectors, concrete objects, wall maps and stick pictures. Of course, we can not change the form too much. That is, the change of forms should be based on the purpose and requirements of teaching. Generally speaking, interesting content can have a longer circle while those uninteresting one should be changed more often. At class, knowledge and interest should be integrated to give students a relaxing atmosphere to study English. In our modern age, the diversified information channels will definitely lead to diversified ways for students to gain knowledge. Accordingly, the former English pattern in which the textbook and teachers are focused on should be changed. Instead, various teaching forms should be employed to cultivate students' learning capacities in the whole teaching process. Therefore, teachers are expected to find out effective teaching methods to create interesting and wonderful teaching atmosphere.

\section{References}

Hu, Chundong. (1990). The Theory of English Teaching. Higher Education Press.

Nunan, D. (1992). Collaborative Language Learning and Teaching, Cambridge: CUP 